\section{form}

Vol I3, No 6 (2020) https://doi.org/10.7577/formakademisk.3875

Peter Haakonsen

Universitetslektor

OsloMet - storbyuniversitetet peterh@oslomet.no

Gitte Skjønneberg

Universitetslektor

OsloMet - storbyuniversitetet

gskjonne@oslomet.no

\title{
Makerspace - Flipped classroom og skapende prosesser
}

\author{
En situasjonsstudie fra UH-sektoren
}

\section{SAMMENDRAG}

OsloMet Makerspace ble i 2019 introdusert i Faglærerutdanningen i design, kunst og håndverk ved Institutt for estetiske fag (EST) ved OsloMet som del av et utviklingsprosjekt. Makerspace ble her prøvd ut $i$ undervisning på tredje studieår, og den teoretiske opplæringen tilbudt som flipped classroom. Sentrale premisser var studentaktiv undervisning og at emneplanens læringsutbyttebeskrivelser ble ivaretatt. Aktuelle læringsutbyttebeskrivelser sorteres i artikkelen under skapende prosesser, og diskuteres ut fra gjennomført- og erfart læreplannivå. Basert på observasjon, studentevalueringer og evaluerende samtale, framkommer det at gjennomføringen på et makerspace går raskt og produktene blir presise, noe som igjen gir produktene et profesjonelt uttrykk. Studien indikerer at makerspaces åpner opp for nye måter å ivareta læringsutbyttebeskrivelsene på. Det er samtidig relevant med kritisk refleksjon over kjennetegn på kvalitet på produktene når en ser forbi fascinasjonen studentene uttrykker over produktenes profesjonelle preg.

Nøkkelord:

makerspace, faglærerutdanning, Kunst og håndverk, bærekraft, skapende prosesser, flipped classroom

\section{INTRODUKSJON - ET BAKGRUNNSTEPPE}

Denne artikkelen tar utgangspunkt i et kurs for tredjeårsstudentene ved Faglærerutdanningen i design, kunst og håndverk (FDKH) på EST ved OsloMet, og kobles til to fagperioder, henholdsvis Entreprenørskap og Design og trykk. Opplæringen på OsloMet Makerspace består av 14 forskjellige moduler, gjort tilgengelig via læringsplattformen Canvas. Studentene skal gjennomføre modulene på egenhånd hvor 
opplæringen er lagt opp med vekt på progresjon og bredde for å imøtekomme læringsutbyttebeskrivelser i emneplanen. Fakultet for teknologi, kunst og design (TKD) ved OsloMet mottok i 2019 støtte fra Direktoratet for internasjonalisering og kvalitetsutvikling i høyere utdanning (DIKU) med fokus påå utvikle studentaktive læringsformer og bruk av skaperverksted, heretter omtalt som makerspace. Fokuset lå i å implementere bruk av OsloMet Makerspace i henholdsvis FDKH (pilot 1), Ingeniør- og teknologifag (pilot 2) og i å utvikle et tverrfaglig valgfag orientert rundt OsloMet Makerspace for hele TKD (pilot 3). Sentralt i alle pilotene er at faglige aktiviteter på et makerspace skal ivareta læringsutbyttebeskrivelsene for de ulike emnene som berøres. Pilot 1 er utgangspunkt for denne artikkelen.

En av faktorene som bidro til at prosjektet fikk støtte fra DIKU, var tidligere utprøving av mulighetene ved OsloMet Makerspace ved tredje studieår på FDKH. Faglærerutdanningen bygger blant annet på en kombinasjon av kunst- og designfag samt fagdidaktikk. I utdanningen reflekterer studentene over hvordan egne praktiske arbeidsprosesser kan gjøres relevant for undervisning i grunnskole og i videregående opplæring. Det er et uttalt mål for DIKU-prosjektet at bruk av OsloMet Makerspace skal bygges opp fra første til tredje studieår på faglærerutdanningen og utvikles som en faglig og relevant læringsarena gjennom studieløpet.

Makerspace, FabLabs og lignende verksteder med andre benevnelser, har eksistert en stund. De senere årene har de også blitt vanligere på skoler og universiteter (Halverson \& Sheridan, 2014). Et kjennetegn ved OsloMet Makerspace er tilrettelegging for aktiviteter i og utenfor undervisning med digitale verktøy som brukes til blant annet 3D-printing, laserkutting og programmering (Mehlum, 2018). En finner ikke nødvendigvis de samme maskinene, verktøyene eller aktivitetene i ethvert makerspace, men mentaliteten som har bakgrunn i bevegelsen the Maker Movement er viktig (Papavlasopoulou et al., 2017). Et makerspace kan være en møteplass der kreativt skapende arbeid skjer i en uformell setting, men det er samtidig rom for formelle aktiviteter slik vi ser det i skole- og universitetssammenheng (Papavlasopoulou et al., 2017). I denne artikkelen handler det spesifikt om erfaringer fra OsloMet Makerspace, men vi bruker også begrepet makerspace mer generelt som en type teknologirikt verksted. I generell form viser da makerspace til et verksted med tilgang til ulik teknologi, og med mulighet til å jobbe kreativt og skapende, enten det er i eller utenfor undervisning.

Aktiviteter på OsloMet Makerspace er integrert i undervisningen for alle tre studieårene i faglærerutdanningen (FDKH). For førsteårsstudentene sin del måtte det justeres inn i en allerede bestemt timeplan fordi prosjektet ble satt i gang først etter at timeplanene for det gjeldende semesteret var lagt. Valget falt på digitale medier, der digital bildebehandling er et sentralt tema. Her kunne noe av opplæringen omhandle tofargede grafiske piktogrammer eller logoer, som senere kunne brukes til vinylskjæring på makerspace. Dette kunne igjen kobles mot tekstil, da vinyltrykk kan festes til tekstiler med varmebehandling. Dette ble et første steg inn i mulighetene som finnes i et makerspace, der forberedelse med digital tegning også er relevant og skal videreutvikles i andre studieår. Andre studieår arbeider studentene med laserkutting i tre, og også her skal motiver bearbeides og forberedes gjennom digital bildebehandling. Når studentene starter sitt tredje år på faglærerutdanningen har de bygget opp sin kompetanse gjennom ulike moduler som vil gjøre dem forberedt på selvstendig arbeid, ulike arbeidsmetoder og gjennomføring. Gjennom prosjektperioden som går over seks uker skal også enkelte studenter rekrutteres til å bli studentmentorer for neste kull. Hensikten med bruk av studentmentorer er å avlaste lærer, samtidig som læringsaktiviteten på OsloMet Makerspace holdes ved like gjennom hele studieåret.

Opplæringen på OsloMet Makerspace har vært systematisk med gjennomføring, observasjon og en evaluerende samtale mellom lærer og hver student. Den tradisjonelle undervisningen ble byttet ut med flipped classroom. Det som tidligere krevde mye av tiden til læreren i klasserommet, for eksempel forelesninger, ble byttet ut med mer tid til diskusjon, praktiske aktiviteter og veiledning. Ved å bruke flipped classroom må studentene forberede seg på læringsstoffet i forkant. Studentene blir gjort ansvarlige for sin egen læringsprosess, og må styre sin egen tid.

Ved å inkludere bruk av OsloMet Makerspace i alle tre årene har det blitt lagt vekt på progresjon og kunnskapsbygging. Det starter med det nære, kjente og konkrete, for så å bygge videre til det mer komplekse når studentene kommer til tredje studieår. Forhåpentligvis vil det stimulere dem til å bli 
nyskapende og bruke mulighetene som finnes i et makerspace på måter som ikke er bestemt på forhånd. Som framtidige faglærere skal studentene kunne reflektere fagdidaktisk over egen praksis, og se sammenhenger mellom egne prosesser og læreplaner for grunnskolen og videregående opplæring. I denne artikkelen blir slike teknologirike verksteder sett i sammenheng med Kunnskapsløftet 2020 (LK20) og læreplan i kunst og håndverk. Ifølge læreplanverkets overordnede del (Udir, 2020a) må bevissthet og kunnskapsbygging bygges i fellesskap for å finne gode løsninger på etisk bevissthet og teknologisk innovasjon som bidrar til nødvendige endringer. Aktiviteter på OsloMet Makerspace kan bidra til et fokus på bevissthet om miljøvennlige valg. Både fordi det som produseres der kan defineres som kortreist, og fordi det legges opp til gjenbruk av eksisterende materialer i tillegg til rester. I andre prosjekter har for eksempel gjenbruk av materialer vært i fokus, og f.eks. papir blitt gjenbrukt som sjablonger. I slike arbeider er den kompetente læreren en viktig aktør som viser til eksempler fra tidligere studentarbeider og hvordan ulike materialer er blitt benyttet til ulike formål.

\section{Gjennomført- og erfart nivå}

I artikkelen søker vi svar på følgende: Hvordan kan læringsutbyttebeskrivelser i faglærerutdanningen på tredje studieår operasjonaliseres innenfor makerspace og med flipped classroom som metode? John Goodlad et al. (1979) beskriver fem læreplannivåer som på ulike måter gir retning for å forstå læreplanpraksis og teori. Vi følger Liv Merete Nielsens (2019) versjon av disse nivåene som er tilpasset norske forhold. Nielsen skiller mellom ideologisk nivå, vedtatt læreplan, tolkningsnivå, gjennomført nivå og erfart nivå. Unders $\varnothing$ kelsen som denne artikkelen bygger på berører det gjennomførte nivået, altså hva læreren gjør, og nivået som omfatter studentenes erfaringer. Læringsutbyttene for kunnskap definert i emneplanen for tredje studieår utgjør vedtatt læreplan, og er benyttet for å gi retning til de teoretiske perspektivene i artikkelen.

\section{Perspektiv på skapende prosesser}

Vedtatt læreplan (Nielsen, 2019) er her avgrenset til å gjelde bestemte læringsutbyttebeskrivelser som ligger til grunn for videre diskusjon. Aktuelle beskrivelser plassert under kunnskap og ferdigheter i emneplanen for det aktuelle studiet omhandler ulike perspektiver som går direkte på skapende arbeid. Flere av disse er fagspesifikke, og knyttet til både materialer, uttrykk og skapende prosesser, inkludert det å kunne bruke samtidens uttrykk innen fagene som referanse for eget skapende arbeid (OsloMet, 2019). Andre læringsutbyttebeskrivelser beskriver prosesser, inkludert ideutvikling, problemløsning og innovasjon, noe som også kan kobles til skapende arbeid. I denne artikkelen sorteres de utvalgte læringsutbyttebeskrivelsene under perspektivet skapende prosesser, noe som synliggjøres i figur 1. Dette perspektivet fungerer som ramme for det som skjer i et makerspace, det vil si gjennomført nivå slik det er beskrevet av Nielsen (2019). Fordi bærekraft også er relevant i denne sammenhengen, markeres også målene som berører dette. 


\begin{tabular}{l|l}
\hline $\begin{array}{l}\text { Kunnskap } \\
\text { Studenten }\end{array}$ & Sortering \\
\hline $\begin{array}{l}\text { har kunnskap om konsum, bærekraft og miljøproblematikk i } \\
\text { fagområdet }\end{array}$ & Bærekraft \\
\hline $\begin{array}{l}\text { har kunnskap om materialer, redskaper og teknikker som er } \\
\text { knyttet til fagområdet formgiving, kunst og håndverk }\end{array}$ & Skapende prosesser \\
\hline $\begin{array}{l}\text { har kunnskap om samtidens uttrykk innen kunst, design og } \\
\text { arkitektur og kan bruke dette som referanse for skapende arbeid }\end{array}$ & Skapende prosesser \\
\hline $\begin{array}{l}\text { har kunnskap om ulike metoder innen skapende arbeid som f.eks. } \\
\text { intuitive og analytiske prosesser, ideutvikling og problemløsning, } \\
\text { entreprenørskap }\end{array}$ & Skapende prosesser \\
\hline $\begin{array}{l}\text { har kunnskap om redskapsbruk, materialbruk og produksjon i et } \\
\text { bærekraftig perspektiv ut fra helse, miljø og sikkerhet }\end{array}$ & Bærekraft \\
\hline $\begin{array}{l}\text { har kunnskap om innovasjon, forskning og utviklingsarbeid innen } \\
\text { fagfeltet }\end{array}$ & \\
\hline $\begin{array}{l}\text { Ferdigheter } \\
\text { Studenten }\end{array}$ & \\
\hline $\begin{array}{l}\text { kan reflektere, drøfte, anvende og vurdere faglig kunnskap på } \\
\text { teoretiske og praktisk-estetiske problemstillinger }\end{array}$ & \\
\hline $\begin{array}{l}\text { kan utforske og vurdere samspillet mellom materialer, redskaper } \\
\text { og teknikker i praktisk arbeid, innen tradisjon og nyskaping }\end{array}$ & Skapende prosesser \\
\hline $\begin{array}{l}\text { kan definere og utføre et FoU-arbeid innen fagområdet } \\
\text { kan bruke digitale medier til innhenting av kunnskap som kreativt } \\
\text { utforskende verktøy i designprosesser }\end{array}$ & Skapende prosesser (indirekte) \\
\hline $\begin{array}{l}\text { kan anvende fagdidaktisk kunnskap og erfaring fra praksis som } \\
\text { grunnlag for skapende arbeid og undervisning }\end{array}$ & Skapende prosesser \\
\hline
\end{tabular}

FIGUR 1: Tabell med læringsutbyttebeskrivelser for kunnskap og ferdigheter, hentet fra emneplan for Faglærerutdanning i design, kunst og håndverk, tredje studieår (OsloMet, 2019).

\section{Bærekraft}

Bærekraft er et gjennomgående tema ved faglærerutdanningen. Aktivitetene på OsloMet Makerspace har vært forankret i FNs bærekraftsmål nr. 12 som handler om ansvarlig forbruk og produksjon (FN-sambandet, 2020). To av læringsutbyttebeskrivelsene i emneplanen for tredjeåret på faglærerutdanningen går direkte inn på bærekraft, både opp mot konsum og miljøproblematikk, og i tilknytning til redskapsbruk, materialbruk og produksjon (OsloMet, 2019). Dette kommer til syne i figur 1. Nøysomhet er et annet viktig prinsipp for ansvarlighet. Hvordan kan vi utvikle produkter som er kortreiste, minske ressursbruken og hindre miljøødeleggelser? Bærekraftig forbruk og produksjon handler om å gjøre mer med færre ressurser. Lærerens rolle er å trene opp studentene. Alt skal kunne omformes til noe annet av verdi for felleskapet for å ha fokus på svinn (Lutnæs \& Fallingen, 2017). Studentene oppfordres til å lage ting lokalt, til resirkulering og gjenbruk, samt bygge fleksibilitet inn i produktene, slik at produkter kan skapes om og dekke nye behov. Ved bruk av verkstedene har vi stor mulighet til å sette små dagligdagse handlinger og meninger inn en større sammenheng og utfordre studenter til å ta ansvar for det de gjør- og det de kanskje velger å ignorere, slik en kunst- og håndverkslærer kan utfordre sine elever, i henhold til Lutnæs og Fallingen (2017). På denne måten vil bærekraft ha en direkte kobling til skapende prosesser, der studenten skal ha en etisk bevissthet omkring egen produksjon uten at dette nødvendigvis skal gå på bekostning av gjennomføringen.

\section{STUDENTAKTIV LAERING OG FLIPPED CLASSROOM}

Studentaktive læringsformer er et premiss for DIKU-prosjektet. I pilot 1 involveres faglærerstudentene i den videre utviklingen og undervisningen, og rekrutteringen av studentmentorer har startet. Gradvis vil det være mulig å styrke nettressursene ved at de videreutvikles i takt med vanlige problemer studentene har og som de ofte spør om. Studentassistenter vil også bidra til å hjelpe studenter ved behov. Det er satt av 125 timer i semesteret/årskull til studentassistenter fra og med høsten 2020. For 
studenter i tredjeåret er det et poeng at de skal jobbe selvstendig og samarbeide med hverandre. Vi bruker flipped classroom, også omtalt som omvendt undervisning. Dette er en metode som snur tradisjonell undervisning på hodet. Flipped classroom vil si at instruksjoner og forelesninger legges tilgjengelig på nettet, mens tiden i klasserommet blir brukt til oppgaveløsning og veiledning med lærer og medelever (Krumsvik, 2016). Instruksjonene som hører til den generelle opplæringen ved OsloMet Makerspace ligger tilgjengelig på nett, og frigir dermed tid til lærer som kan gå rundt og veilede. Dette metodiske grepet gir større rom for å tilrettelegge for at hver student kan jobbe i sitt tempo. Før de kan arbeide i lokalene til OsloMet Makerspace må alle studentene fullføre en sikkerhetsavtale for maskinene som skal brukes. Dette avsluttes med en obligatorisk sikkerhetssjekk. Studentene velger den modulen de er interessert i, og må lese pensum. Det kan også innebære praktisk trening. Andre moduler er valgfrie. Seymour Papert og hans konstruksjonisme, basert på Piagets konstruktivisme, blir ofte koblet til læring og arbeidsmetoder i slike makerspaces (Keune \& Peppler, 2018). Et poeng med konstruksjonismen er læring gjennom handling der møtet med konkrete objekter eller materialer står sterkt (Ackermann, 2001).

Organisering og opplegg krever at studentene tar ansvar med forberedelser $f \varnothing r$ det praktiske arbeidet starter i lokalene på OsloMet Makerspace. I følge Raaheim og Nysveen (2019) har denne formen for undervisning et potensial til å øke kvaliteten på undervisningen da studentene får en større frihet til å velge tid og sted, noe som igjen gjør det mulig for lærer å gi mer tid til veiledning til hver student. Flipped-tilnærmingen er i bruk både i studiets fagspesifikke kurs og i den generelle opplæringen for bruk av verktøy og maskiner. Opplæringsmateriell tilhørende den generelle opplæringen er tilgjengelig for studentene gjennom OsloMet Makerspace sitt Canvas-rom. Komponentene i opplæringsdelen er vist i figur 2. I tillegg suppleres det med fagspesifikke ressurser knyttet til KH-fag, utviklet av lærer.

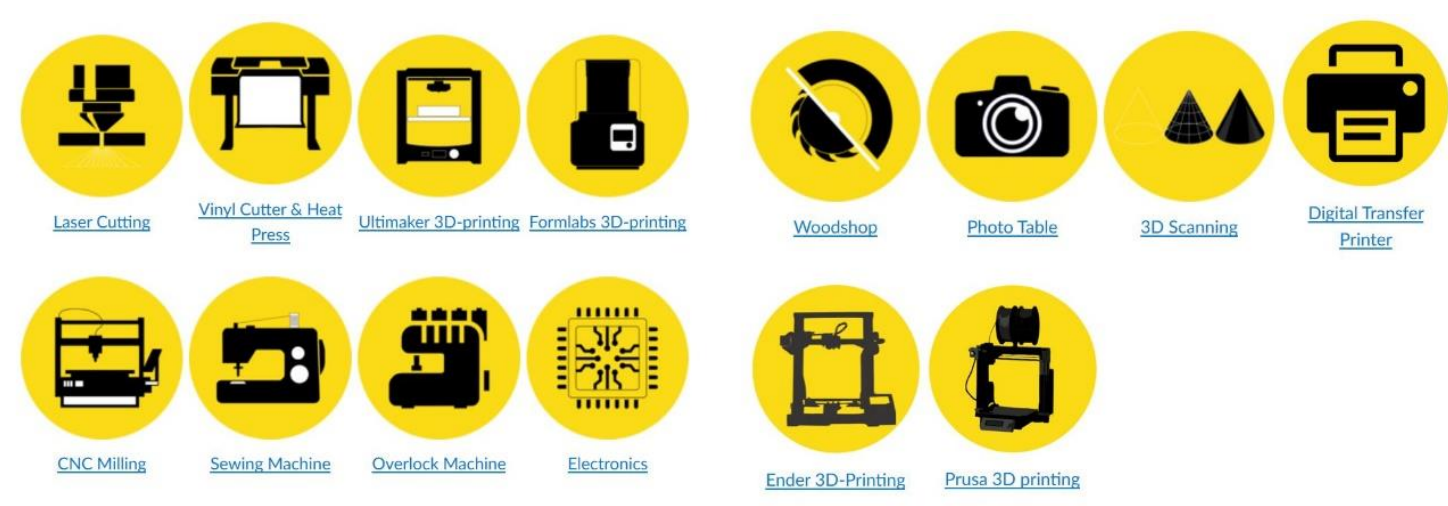

FIGUR 2: De ulike modulene i Canvas som studentene må gjennomføre før de kan bruke utstyret på makerspace. Skjermbilde fra OsloMet Makerspace /Canvas.

Et sentralt element ved flipped classroom er å overlate noe av kontrollen til studentene, for på den måten å øke deres opplevelse av tilhørighet til og mestring av faget (Krumsvik, 2016). I følge Akçayır og Akçayır (2018), som har gjennomført en studie med resultatet fra 71 ulike forskningsartikler, er en av de store fordelene med denne modellen at den kan bidra til å forbedre læringsytelse hos studentene. Studentene må planlegge tiden sin og forstå læringsinnholdet utenfor klasserommet. Fleksibiliteten gjør at studentene kan studere i sitt eget tempo (2018). Lærerens rolle endres fra å være en formidler av kunnskap til å bli en tilrettelegger for læring (Raaheim \& Nysveen, 2019). Risikoen er at en uforberedt student ikke vil ha forutsetning til å delta i aktivitetene på campus. En annen ulempe er at studenten ikke får mulighet til å stille spørsmål underveis, når de går igjennom fagstoffet på egen hånd (Akçayır \& Akçayır, 2018). I vårt tilfelle er ikke det siste problemet så stort, da studentene også får praktisk opplæring i utstyret på OsloMet Makerspace. Flipped-tilnærmingen fungerer best når studenter kommer forberedt. En utfordring er at det varierer hvor mange studenter som 
stiller forberedt. Akçayır og Akçayır bekrefter også at en av utfordringene er knyttet til aktiviteter utenfor klasserommet, som f.eks. at forberedelser før undervisning er mangelfulle.

\section{METODISK TILNAERMING}

Studien denne artikkelen bygger på er del av et større prosjekt der flere piloter inngår. Selve prosjektet genererer et omfangsrikt datamateriale. I denne artikkelen ser vi nærmere på en konkret læringssituasjon der studenter ved faglærerutdanningen får erfaring med OsloMet Makerspace som læringsarena. Selv om bruk av et makerspace i undervisningen er nytt for disse studentene, bygger selve undervisningskonseptet på lærerens tidligere erfaringer. Lang undervisnings- og veiledningserfaring har bidratt til å frambringe problemstilling, retning og form på selve undersøkelsen, men også vært nyttig for drøftingene i kjølvannet av det studerte. I gjennomføringen av undervisningskonseptet har lærer vært aktivt deltagende, både gjennom deltagende observasjon av studentens læringsprosesser og i drøfting av deres valg underveis i det praktiske arbeidet. Studentenes praktiske arbeider er dokumentert på Padlet, en felles digital tavle på internett (Padlet, n.d.). En vesentlig del av denne spesifikke studien har vært evalueringssamtaler med hver av studentene etter gjennomført kurs. Dokumentasjon på praktisk arbeid via Padlet har gitt lærer et helhetlig innblikk i studentenes prosess. Denne artikkelen konsentrerer seg om momenter studentene trekker fram i evalueringssamtalene, samt lærers observasjon i undervisningen.

Studien har likhetstrekk ved det Alvesson (2014) beskriver som situasjonsstudier. Situasjonsstudier kan ses som en motsats til tradisjonelle studier av institusjoner og organisasjoner der hovedfokuset ofte er på systemer og strukturer og der selve organisasjonen studeres på et overindividuelt nivå. Ved å gå ut fra en konkret situasjon innenfor en institusjonell kontekst blir individene mer tilstedeværende i studien, men likevel ikke som eksplisitte individer. "Det är sällan eller aldrig en fråga om at 'rena individer' framträder utan dessa präglas starkt av den scen i hvilket de verkar" (Alvesson, 2014, s. 39). Alvessons framstilling av situasjonsstudier har blant annet preget Karen Brænnes (2009) avgrensning av eget PhD-prosjekt. Det empiriske materialet var hentet fra to oppgaveperioder ved en årsenhet i kunst og håndverk ved en norsk allmennlærerutdanning. I denne studien er det utsagn hentet fra evalueringssamtaler med tredjeårsstudenter knyttet til et spesifikt kurs på OsloMet Makerspace som utgjør datamaterialet. Utsagn er dokumentert ved hjelp av Padlet. Studentenes utsagn ble dokumentert av ansvarlig lærer, som er andreforfatteren av denne artikkelen. Det er ikke de enkelte svar som er interessante her, men heller utsagn som kan vurderes som representative for flertallet av studentene. Slik blir utsagn her sett på som uttrykk for studentenes erfaringer og refleksjoner mer generelt, framfor å representere enkeltindivider.

\section{GJENNOMF $\varnothing$ RING}

Tredje studieår består av tre parallelle grupper. Gruppene er igjennom samme opplæring på OsloMet Makerspace. Avslutningsvis er det gjennomført en evaluerende samtale med hver student, med noen enkle spørsmål og dokumentasjon på Padlet. Unders økelsen tar utgangspunkt i alle studenter som går tredje studieår. De har minimal erfaring fra makerspaces, men skal ha forberedt seg gjennom tilgjengelige nettressurser. Mulige aktiviteter på OsloMet Makerspace er i forkant tilpasset undervisningen i tredje studieår og knyttes til to fagperioder med henholdsvis Entreprenørskap og Design og trykk. I fagperioden Entreprenørskap brukes mulighetene som finnes på OsloMet Makerspace til produktutvikling og målet er at et fysisk produkt skal presenteres. Figur 3 viser et eksempel på et produkt som er laget med en 3D-printer. Gjennom utvikling av produkter skal studentene vurdere og beskrive fornyingsbehovet i faget (generell kompetanse). 


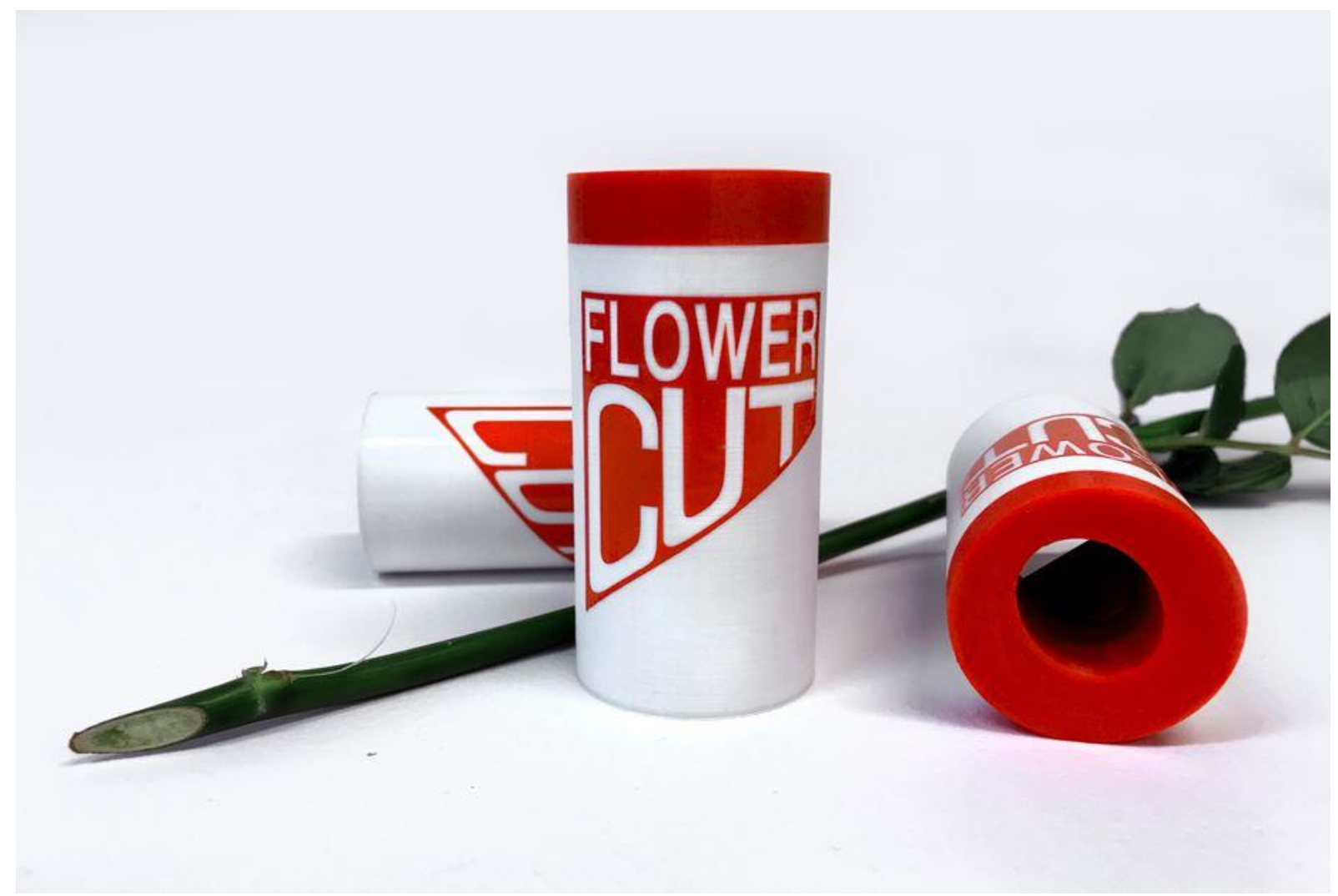

FIGUR 3: Studentarbeid. Eksempel på en prototype av en forretningsidé (Flowercut) som ble presentert i Oslo-mesterskapet for entreprenørskap.

I fagperioden med Design og trykk brukes blant annet laserkutteren på OsloMet Makerspace til utvikling av trykkblokker, som vises i figur 4 og 5 . Det er gode muligheter for å arbeide med ulike trykk til utskjæring av sjablong til små og store arbeider, som igjen kan brukes til bilder, klær, tekstiler, og arbeid i store format som Street art.

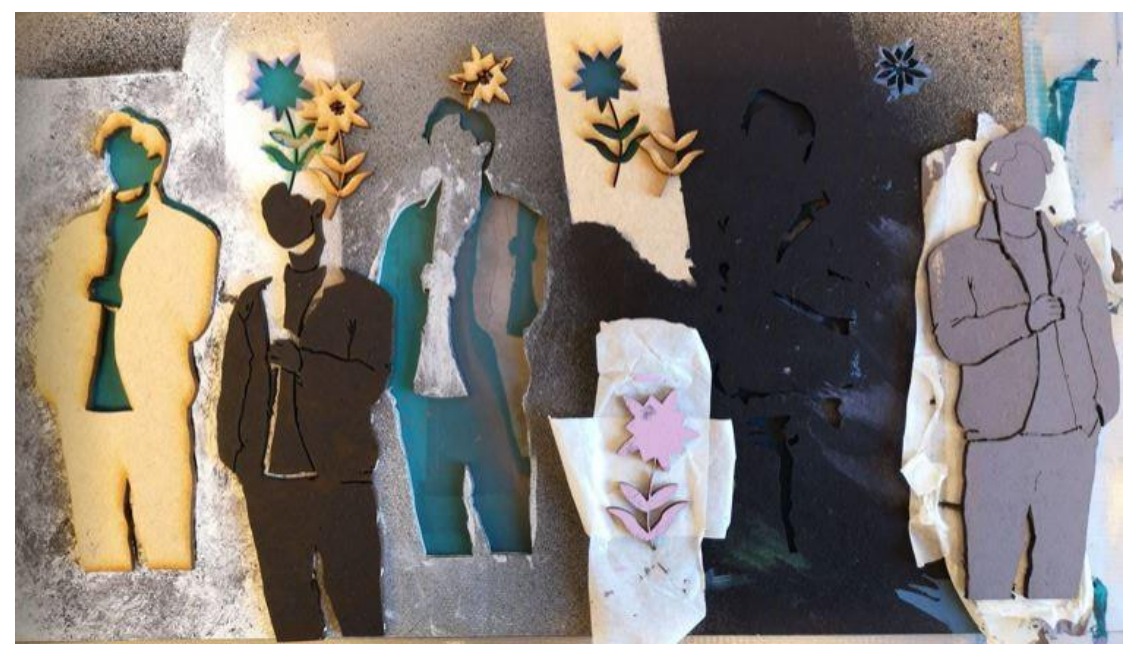

FIGUR 4. Studentarbeid. Ulike trykkblokker som er laget med laserkutter på OsloMet Makerspace. Trykket skal bli flerfarget, og består av flere ulike lag. 


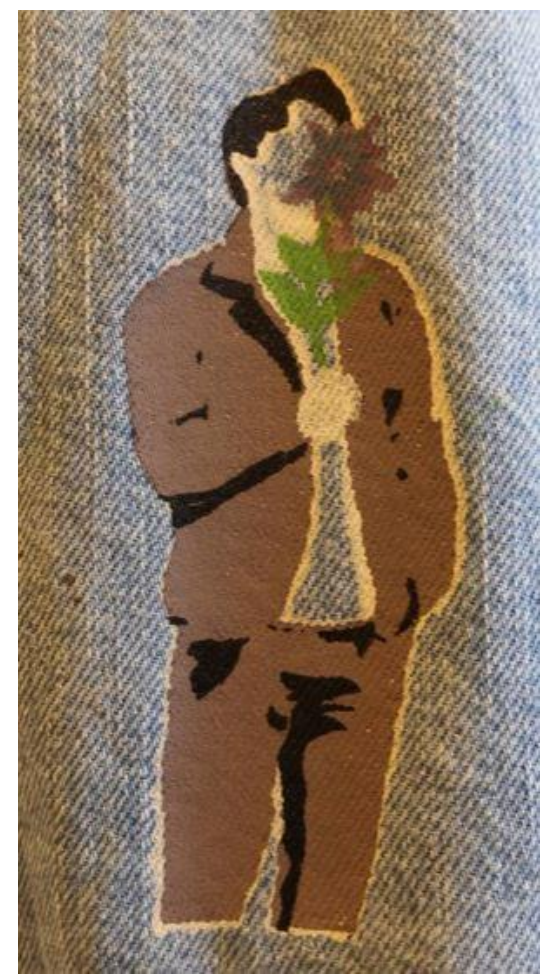

FIGUR 5: Studentarbeid. Ferdig trykk på tekstil med trykkblokker i flere lag.

Gjennom å lære ved å gjøre får studentene kunnskap gjennom praksis. De ser muligheter for hvordan de kan anvende dette videre i oppgaver som f.eks. sublimering, trykk på klær, fresing av egne trykkplater til grafikk, mal for keramikkprodukter, digital tegning/broderi med fres, blanding og kombinasjoner av teknikker. Slik er læringsaktivitetene å regne som formelle, altså definert som obligatoriske oppgaver med klare mål (Einarsson \& Hertzum, 2020). I denne sammenhengen vil flipped classroom-kursene kategoriseres som ikke-formelle (non-formal), som ifølge Einarsson og Hertzum defineres blant annet som aktiviteter med mål om å utvikle spesifikke ferdigheter i et makerspace. Dette kan for eksempel være opplæring i bruk av bestemte verktøy og maskiner, som for eksempel en laserkutter eller 3Dprinter. Aktiviteter og prosjekter som studentene utfører på eget initiativ kalles her uformelle (informal) (Einarsson \& Hertzum, 2020).

\section{Evaluerende samtale}

Padlet fungerer som en digital og interaktiv oppslagstavle som studentene har tilgang til, og er her brukt til dokumentasjon av studentenes arbeid gjennom begge fagperiodene. Studentene legger inn bilde av ferdig resultat sammen med en kort faglig beskrivelse. Etter hver fagperiode blir studentene invitert til en evaluerende samtale med faglærer. Studentene kommer med kommentarer og innspill til forbedringer etter hva de har gjort og erfart fra perioden. Spørsmålene som ble tatt opp i samtalen var:

1. På hvilken måte kan makerspaces brukes i undervisning for elever i grunnskolen og videregående opplæring?

2. Hva gjør at OsloMet Makerspace kan være et supplement til undervisningen på faglærerutdanningen?

3. Muligheter og utfordringer med et makerspace.

I denne sammenhengen er studentenes erfaringer fra OsloMet Makerspace utgangspunkt for spørsmålene, men her er det også relevant å se på makerspaces mer generelt, altså som lignende 
verksted som kunne vært på andre skoler. Dette er spesielt framtredende i første og siste spørsmål. Det er til sammen 27 studenter som har deltatt i evaluerende samtale. En gjennomlesning av svarene viser at det er noen momenter som går igjen i tilbakemeldingene. Nedenfor er det hentet ut enkeltsvar som er dekkende for det flere studenter melder tilbake om. Svarene som er valgt ut er ment å få fram den mest relevante informasjonen som peker i retning av hvordan et makerspace kan inngå i undervisning både i grunnskole, videregående opplæring og i faglærerutdanningen.

\section{RESULTATER}

Nedenfor er det valgt ut representative utsagn fra evalueringssamtaler med studentene. På spørsmål nr. 1 er det flere studenter som trekker fram muligheten for tverrfaglig samarbeid. På spørsmål nr. 2 er det tydelig at teknologisk utvikling er i fokus. En student uttrykker seg slik: «Det går raskere enn det analoge, og med bedre resultat». En annen sier at «dette er framtiden». I siste spørsmål, nr. 3, er det en overvekt som svarer «alt vi lager blir helt perfekt». Noe som også går igjen er at «det ser kjøpt ut», eller «alt kommer opp på et høyere nivå». Noen studenter synes at det blir mye dødtid, da maskinene gjør nesten all jobb med å framstille produkter, mens andre ser at tiden kan brukes til å utvikle nye ideer når de ser at prosessen er i gang og forstår mulighetene. Resultatene viser at studentene blir fornøyde med produktene som blir laget på et makerspace. De får større bevissthet om teknologi og ulike dataprogrammer som er helt nødvendig for å følge den digitale utviklingen.

Flere studenter gir uttrykk for at de trenger mer trening i ulik programvare som brukes i tilknytning til ulike maskiner og verktøy på OsloMet Makerspace, noe som kommer fram gjennom samtaler basert på spørsmål nr. 3. Sjekklister knyttet til vanlige problemer vil også være en mulig strategi for å redusere behovet for hjelp og teknisk assistanse. Arbeidet står ofte på vent da mange er avhengig av mye hjelp. Samtidig skal flere av nettressursene bidra til at denne køen bli kortere enn den ville vært dersom det ikke var fokus på egenstudier i form av video og oppskrifter. Det disse flipped classroomressursene ikke alltid fanger, er uforutsette problemer som studentene erfarer.

Gjennom observasjon har lærer registrert at ved utvikling av produkter går selve gjennomføringen raskt, noe som gir muligheter til bl.a. mer eksperimentering og utprøving på produktutvikling. Ifølge svar på spørsmålene som ble besvart var alle studentene fornøyd med å lage produkter på makerspace. Dette ble synliggjort på ulike måter gjennom alle tre spørsmålene. Som begrunnelse framheves det at produktene som ble laget ble presise, med et profesjonelt uttrykk. Studentene tar utgangspunkt i aktuelle problemstillinger som krever engasjement. Gjennom samarbeid finner de gode løsninger som resulterer i produkter de blir stolte av. Studentene ser verdien i skaperglede og konkluderer med å ta i bruk egne erfaringer videre ut i grunnskolen når de skal undervise egne elever, ifølge spørsmål nr. 1. Dette er i tråd med beskrivelser om skaperglede i læreplanverkets overordnede del, der kreativt skapende arbeid og samarbeid settes i sammenheng med nytenkning, entreprenørskap og problemløsning (Udir, 2020b).

Produktutvikling tar tid, og det gir mulighet for refleksjon og samtaler. Det er ved å gjøre at mulighetene oppstår. I samtalen forteller en student: «Det er i ventepausene vi får de beste ideene». Studentene blir motivert ved å bruke gratis gjenbruksmaterialer fra tidligere prosjekter, og ser gode muligheter for nye produkter. Dette bekreftes av en annen student som sier: «Mens vi venter, går vi rundt og titter i restekassene etter gratis materialer». Resultatet fra kursevalueringene som er rapportert her indikerer at tilgang på et makerspace er et godt supplement for lærere i kunst- og håndverksfag, da muligheten for å kombinere noe av det moderne med det tradisjonelle kommer tydelig fram i de evaluerende samtalene.

\section{DRøFTING}

Innledningsvis spurte vi hvordan læringsutbyttebeskrivelser i faglærerutdanningen på tredje studieår kan operasjonaliseres innenfor makerspace og flipped classroom. Etter gjennomføringen ser vi noen interessante momenter som vi går videre med her. Basert på de tre spørsmålene fra evaluerende 
samtale med studentene, og som er en konkretisering av denne artikkelens tema - kan vi se en viss tendens?

\section{Skaperglede i fagfornyelsen}

Faglærerutdanningen forbereder studentene på lærerrollen ved at de får erfaringer med oppgaver som vil være relevante ute $\mathrm{i}$ skolen. Bruk av et makerspace i utdanning kan ses i sammenheng med kompetansebegrepet beskrevet i Kunnskapsløftet 2020. Her er det sentralt at eleven skal kunne bruke sin kompetanse til å løse problemer i kjente og ukjente situasjoner. Slik er det formulert i læreplanverkets overordnede del, under Prinsipper for læring, utvikling og danning: "Kompetanse er å kunne tilegne seg og anvende kunnskaper og ferdigheter til å mestre utfordringer og løse oppgaver $\mathrm{i}$ kjente og ukjente sammenhenger og situasjoner" (Udir, 2020c). Ser en i tillegg på Utdanningsdirektoratets beskrivelse av algoritmisk tenkning (2019), finner en begreper og arbeidsmåter som støtter opp under det å prøve seg fram og tenke selvstendig for å definere og løse problemer. Her framheves også det å stå i problemet, og holde ut, sammen med skaperglede, samarbeid, fikling (fra engelsk tinkering) og eksperimentering. Disse begrepene er nært knyttet til læreplanens verdigrunnlag der skaperglede er framhevet (Udir, 2020b). Lutnæs \& Fallingen (2017) beskriver at gjennom skapende prosesser kan man oppdage løsninger og problemer man ikke hadde forutsett i forkant av prosjektet, oppleve at den fysiske inngripen i materialene påvirker resultatet og slik kanskje kan lære å anerkjenne verdien i egeninnsats. Dette kan ses i sammenheng med tinkerbegrepet, som gjerne beskrives som en åpen prosess med ukjent utfall, der "møtet" med et materiale eller et verktøy bidrar til å påvirke og drive den skapende prosessen videre (Lewis \& Thurman, 2019; Haakonsen \& Fauske, 2019). Vi velger heretter å bruke det engelske begrepet tinker, da det er vanskelig å oversette med et like dekkende ord på norsk.

Digitale ferdigheter inngår som grunnleggende ferdighet i læreplan i grunnskole og videregående skole (Udir, 2020d). Dette er også relevant å se i sammenheng med skaperkraft, programmering og algoritmisk tenkning (Kunnskapsdepartementet, 2019; Udir, 2019; Udir, 2020b). I læreplanverkets overordnede del, under opplæringens verdigrunnlag, kobles skaperglede, engasjement og utforskertrang til dybdelæring (Udir, 2020b). Her framheves også tidligere nevnte arbeidsmåter som fikling og eksperimentering, som en kjenner igjen fra arbeidsmåtene forbundet med algoritmisk tenkning (Udir, 2019). Betydningen som digitale ferdigheter har i ny læreplan stiller krav til lærerutdanningene, herunder også faglærerutdanningen i design, kunst og håndverk. Hetland \& Solum (2008) viser til at norsk lærerutdanning henger etter når det gjelder integrering og bruk av IKT i undervisningen. Etter at koronakrisen rammet Norge i mars 2020, har det skjedd store endringer i bruk av IKT. Lærere har måtte omstille seg, og kompetanseutvikling har vært helt nødvendig (Bolstad, 2020).

\section{Hva tilfører makerspace undervisningen?}

Muligheter en har i et makerspace skiller seg ut fra tradisjonelle håndverksteknikker blant annet på grunn av raskt og presis produksjon. Dette kan frigjøre tid i prosessen. Det er i selve utarbeiding av produkter mulighetene for nye ideer og løsninger dukker opp. Dette gir studentene en stor fordel i arbeid med produktutvikling der de kan prøve ut flere iterasjoner og gjøre små justeringer fram til de sier seg fornøyd med sine endelige resultater. Samtidig er det relevant å ha en kritisk holdning til ressursbruk. Materialer som blir til overs samles og brukes på nytt. Studentene forteller at det er en stor motivasjon at restmateriale er gratis, og at dette bidrar til en forståelse for valg av materialer og miljøhensyn. Lutnæs og Fallingen (2017) beskriver i sin artikkel at målsetningen om et mer bærekraftig samfunn kan bare nås gjennom handling, noe som går igjen med hvordan egne holdninger og handlingsmønster påvirker muligheter for utvikling.

De to fagperiodene Entreprenørskap og Design og trykk, som ligger til grunn for denne artikkelen, dekker flere av de utvalgte læringsutbyttebeskrivelsene som vi har sortert under skapende prosesser, i tillegg til bærekraft. Da disse er åpne og kan kobles til flere ulike fagdisipliner og verksteder, vil faglærers avgjørelser når oppgaven defineres gi lokale variasjoner i hvordan målene er operasjonalisert. Slik kan aktiviteter i et makerspace være en alternativ måte å dekke de fleste læreplanmålene på, og summen av de ulike fagperiodene studentene opplever gjennom studiet vil bidra 
til variasjon i hvordan enkelte mål er operasjonalisert av de ulike lærerne. Bruken av OsloMet Makerspace er inkludert i en del av undervisningen der det er relevant, men ikke i all undervisning. Studentene melder fra om at det er givende å produsere med maskinene som bidrar til det industrielle preget, noe som altså ser ut til å være en viktig motivasjonsfaktor. Studentene hadde i forkant skåret ut sjablonger for hånd slik at de var kjent med prosessen og hvordan de skulle gå fram for å få et godt resultat uten hjelp av maskiner. Dermed hadde de håndverksteknikken og -forståelsen inne når nye sjablonger skulle utformes digitalt og lages gjennom ulike verkt $\varnothing y$ og maskiner. Uttrykket i det som lages på et makerspace gir en kontrast til det analoge da det blir mer presist og detaljert. Responsen var at studentene opplevde dette som relevant for framtidens kunst- og håndverksundervisning. Det studentene eventuelt måtte gå glipp av når de lar en maskin gjøre deler av jobben, kompenseres ved at de gjør et grundig forarbeid i den digitale tilretteleggingen $f \varnothing r$ en fil sendes til en maskin. Den grunnleggende forståelsen av håndverksteknikken er en forutsetning for å ha kontroll på sluttresultatet. Dette innebærer forståelse av linjer som skal henge sammen, og riktig størrelse på sjablongen. I tillegg skal sluttproduktet trykkes for hånd. Det vil si at det som produseres på et makerspace fungerer som et ledd i en st $\varnothing r r e$ prosess, der en maskin gjør den delen av arbeidet som den gjør bedre enn et menneske, nemlig å skjære ut en sjablong på en nøyaktig måte.

\section{Muligheter og utfordringer}

I forkant av opplæringen ble flipped classroom brukt når studentene skulle gjennomgå de ulike modulene for opplæring på OsloMet Makerspace. Modulene består av opplæringsmateriell knyttet til de ulike maskinene og programvarene der, og gås igjennom individuelt i forkant. Disse avslutter med en sikkerhetssjekk for å kvalitetssikre at studenten har lest grundig igjennom materiellet, og er klar for å få den praktiske opplæringen i maskinene på makerspace. Ikke alle studentene var like forberedt. Den fleksibiliteten som flipped classroom gir kan være utfordrende for mange studenter. Akçayır og Akçayır (2018) beskriver også utfordringer med denne modellen, som aktiviteter utenfor klasserommet med mangelfull forberedelse $f \varnothing r$ undervisningen. Nysveen og Raaheim (2019) bekrefter gjennom sine undersøkelser med studentaktiv læring at det ikke er urimelig å anta at det vil kreve en viss modenhet hos studentene. Gjennom artikkelen til Akçayır og Akçayır (2018) viser resultatene at en av fordelene ved denne modellen er en forbedring av læringsytelsen som er et av sentrale elementer $\mathrm{i}$ kvalitetsopplæringen. Ifølge samtale med studentene øker engasjementet ved fleksibilitet og ansvar for egen tid og læring. Studentene ser at teknologien gjør det mulig å legge til rette slik at opplæring kan skje hvor som helst og når som helst.

I den evaluerende samtalen med studentene kom det et $\emptyset$ nske om å lage noe mer enn prøver og prototyper. De ønsker å skape «ekte» produkter. Ifølge studentenes tilbakemeldinger får vi et visst inntrykk av hva de sitter igjen med av kunnskap. Sett i lys av emneplanens erfarte nivå, jamfør Nielsen (2019), kan vi se av det innsamlede materialet fra studentene at deres opplevelse gir gode føringer for videre arbeid $\mathrm{i}$ et makerspace. Studentene $\emptyset$ nsker å produsere og bruke erfaringer de har fått og gå videre med produktutvikling. Samtidig blir det ikke et produkt uten en prosess, noe emneplanen for det aktuelle studiet også legger vekt på i to av læringsutbyttebeskrivelsene (OsloMet, 2019). Studentene skal også kunne formidle verdien av en prosess til sine egne framtidige elever, noe som inkluderer åpne og intuitive framgangsmåter. Dette kan kobles til begrepet tinkering. Resnick \& Rosenbaum (2013) trekker fram verdien av å legge vekt på prosess framfor endelig produkt. Slik kan eksperimentering og feiling i større grad være viktige deler av en prosess, og at deltakere også dokumenterer og diskuterer og reflekterer over dette underveis.

\section{"The keychain syndrome"}

De tidligere nevnte læringsutbyttebeskrivelsene knyttet til både bærekraft, fagspesifikke materialer og skapende arbeid, er kunnskapsmål som er relevante innenfor flere fagdisipliner i studiet. De kan hektes på både nye og tradisjonelle fag, i spennet mellom todimensjonale bildeuttrykk, harde, myke og plastiske materialer, og digitale medier. Bruken av makerspace i dette tilfellet har vært i spennet mellom det nye og det tradisjonelle, og bygger også på trykk-kurs gjennomført tidligere. Det som har vært annerledes med et makerspace, er rask gjennomføring og presis utforming, og nettopp dette 
profesjonelle uttrykket som studentene beskriver. Det framgår i samtalene med studentene at det beste er at det ser profesjonelt ut. Det profesjonelle beskrives som presise kanter, linjer og presis kutting, og at det går raskt å produsere. Blikstein (2013) beskriver gjennom sitt arbeid med studenter et fenomen han omtaler som the keychain syndrome. En studentoppgave som gikk ut på å produsere egne nøkkelringer med laserkutter, etter først å ha designet dem med et tegneprogram, medførte stor entusiasme og mestringsfølelse. Produktene ble beundret og ga en stor belønning for en relativt liten innsats. Samtidig ledet det til at studentene heller ville masseprodusere nøkkelringer i stedet for å gå Iøs på lærerens neste og mer krevende oppgaver. Dette kan også relateres til Christensen et. al (2019) som i en unders $\varnothing$ kelse på mellomtrinnet trekker fram hvordan entusiasmen over det teknologiske muliggjør utvikling av digitale produkter i kortere workshops. Dette settes i motsetning til mer komplekse designprosesser der sluttresultatet ikke er forhåndsbestemt. Men det at det er utført av studentene selv og ser «kjøpt» ut kan altså være en motivasjonsfaktor. Dette kan være en tankevekker som viser at lærerens rolle også er å stille spørsmål ved hva som er de faktiske kvaliteter i et produkt, både når det bærer preg av å være hjemmelaget og når det ser masseprodusert ut. Det henger også sammen med vurderingskriteriene til den aktuelle oppgaven, noe som ligger utenfor hva denne artikkelen unders $\varnothing$ ker.

I arbeidet med sin PhD har Ingvill Maus (2019) intervjuet ungdomsskoleelever og blant annet bedt dem om å foreslå en pris på deres egenproduserte elevarbeider i keramikk. Dette syntes de var vanskelig da de mente at elevarbeider ikke kunne sammenlignes med industrielt produserte bruksgjenstander, hverken med tanke på pris eller bruksverdi. I deres фyne var håndlagde elevarbeider ikke verdt noe særlig sammenlignet med profesjonelt utviklede produkter. Som bruksgjenstander var de ifølge elevene heller ikke av verdi, men mer som dekorative artefakter å regne. Vi skal ikke trekke slutninger fra empiri gjort med ungdomsskoleelever over til denne artikkelens unge, voksne studenter. Men her er vi inne på et område for videre forskning, med motivasjon, bruksfunksjon og bærekraft knyttet til kunst og håndverk, med og uten tilgang til et makerspace. Hvor dypt stikker fascinasjonen for de profesjonelle uttrykk i egne arbeider, og er det mulig å artikulere og definere hva dette egentlig betyr? Er det ulik grad av profesjonalitet i et slikt uttrykk, og hvordan ville for eksempel Maus' elever sette en pris på egne arbeider dersom disse var utviklet i et makerspace?

\section{Videre forskning og kritisk tilbakeblikk på egen studie}

Spørsmålene studentene svarte på i evalueringssamtalene ble utformet med tanke på å frambringe innsikt som kunne nyttiggjøres i forskningssammenheng. I ettertid ser vi at noen av spørsmålene kunne blitt utformet annerledes. Dette ser vi spesielt i de to første, som kan gå litt i hverandre. Likevel ser vi at evaluerende samtale med studenter har gitt oss verdifull innsikt som kan bidra til å videreutvikle undervisningen på OsloMet Makerspace ved faglærerutdanningen. Innsikter fra denne undersøkelsen har også gitt anslag for framtidige forskningsspørsmål. Alvesson (2014) peker på at en ulempe med situasjonsstudier er at selve studien er begrenset i tid og rom, og den er representativ. Denne type studie forteller ikke hele historien om det studerte (Alvesson, 2014, s. 39). Det kunne for vår del være interessant å følge studentene videre, og se hvordan de som uttrykker fascinasjon for det profesjonelle uttrykket forholder seg til dette når de har fått enda mer erfaring og faglig fordypning i et makerspace. En utfordring med studien som er gjort er at situasjonsfokuset kan ha ført til at noen aspekter har blitt framhevet i for sterk grad, mens noe annet kanskje har blitt oversett, eller ikke tillagt nok vekt. I en videre oppfølging av denne studien kan det være hensiktsmessig med et bredere tilfang av datamateriale. Et alternativ er å engasjere flere studenter innenfor en gruppe i samtale om erfaringer med mulighetene i et makerspace, da gjennom fokusgruppeintervju. Et annet alternativ kan være å sette i gang en studie der studenter følges gjennom alle studieårene og der erfaringer med skapende prosesser i et makerspace vokser fram over tid.

Erfaringer fra tre år med OsloMet Makerspace viser at enkelte studenter velger å bruke mye tid her, både på skolerelatert arbeid for eksempel i forbindelse med eksamensprosjekter (formelle aktiviteter), og til privat bruk (uformelle aktiviteter). Disse entusiastene tar del i skaper- og delingskulturen som preges av skaperverksteder over hele verden. Egne produkter blir utviklet, ideer 
blir testet ut, og det er også mulig å reparere ting en har, for eksempel gjennom lodding, søm eller 3Dprinting. Denne kombinasjonen av skapervirksomhet og vedlikehold gjør et makerspace til et sted der mange vil oppdage nye muligheter og bruksområder innenfor og utenfor skolearbeidet. Nettopp dette engasjementet, delingskulturen og holdninger til både skapervirksomhet og bruken av ulike typer makerspaces som læringsarena ville det være svært interessant å hente fram mer kunnskap om. Tilsvarende ville det være interessant å se nærmere på bruken av studentassistenter på OsloMet Makerspace. Hva skjer når studenter lærer av hverandre?

OsloMet Makerspace var i nyhetene i forbindelse med koronautbruddet i mars 2020, med produksjon av verneutstyr til helsepersonell (Kolberg \& Tahir, 2020). Dette er et eksempel på at makerspaces kan bidra til lokal produksjon kombinert med faglige utprøvinger. Det gjenstår å se hvilket mangfold bruken av makerspaces i Faglærerutdanning i design, kunst og håndverk kan bidra til. Vi mener å se at tilgangen til et makerspace er et viktig bidrag gjennom hele studieløpet i faglærerutdanningen, og har en sentral plassering i forberedelsen til læreryrket. 


\section{REFERANSER}

Ackermann, E. (2001). Piaget's Constructivism, Papert's Constructionism: What's the difference? http://learning.media.mit.edu/content/publications/EA.Piaget\%20_\%20Papert.pdf

Akçayır, G., \& Akçayır, M. (2018). The flipped classroom. A review of its advantages and challenges. Computers \& Education, 126(November), pp. 334-345. https://doi.org/10.1016/j.compedu.2018.07.021

Alvesson, M. (2014). Kommunikation, Makt, Organisation.Närläsning och multipla tolkningar. Studentlitteratur.

Blikstein, P. (2013). Digital Fabrication and 'Making' in Education: The Democratization of Invention. In J. WalterHerrmann \& C. Büching (Eds.) FabLabs: of Machines, Makers and Inventors, (pp.204-220). Transcript Publishers. https://doi.org/10.14361/transcript.9783839423820.203

Bolstad, E. (2020, 13. mai). Kommentar: Innovasjon i krisetider. Koronakrisen gir muligheter for innovasjon og kompetanseutvikling. Karriere360. https://karriere360.no/artikler/koronakrisen-gir-muligheter-forinnovasjon-og-kompetanseutvikling/487548

Brænne, K. (2009). Mellom ord og handling. Om verdsetjing i kunst og handverksfaget [PhD, Arkitektur- og designhøgskolen i Oslo]. Oslo. http://hdl.handle.net/11250/2406784

Christensen, K.S., Hjorth, M., Iversen, O.S., \& Smith, R.C. (2019). Understanding design literacy in middle-school education: assessing students' stances towards inquiry. International Journal of Technology and Design Education 29, 633-654. https://doi.org/10.1007/s10798-018-9459-y

Einarsson, A. M., \& Hertzum, M. (2020). How is learning scaffolded in library makerspaces? International Journal of Child-Computer Interaction, 26(December), 1-9. https://doi.org/10.1016/j.ijcci.2020.100199

FN-sambandet. (2020). FNs bærekraftsmål. https://www.fn.no/Om-FN/FNs-baerekraftsmaal

Goodlad, J. I., Klein, M. F., \& Tye, K. A. (1979). The Domains of Curriculum and Their Study. In Q. Thomas H. \& M. Hennelly (Eds.), Curriculum Inquiry. The Study of Curriculum Practice (pp. 43-76). McGraw-Hill Book Company.

Haakonsen, P., \& Fauske, L. B. (2019). Learning to create images with computer code. Conference proceedings of the Academy for Design Innovation Management. (pp.1220-1231). ADIM. https://oda.oslomet.no/handle/10642/8272

Halverson, E. R., \& Sheridan, K. (2014). The maker movement in education. Harvard Educational Review, 84(4), 495-504.

Hetland, P., \& Solum N. H (2008). Digital kompetanse i norsk lærerutdanning. Rapport 28/2008. NIFU-STEP.

Keune, A., \& Peppler, K. (2018). Materials-to-develop-with: The making of a makerspace. British Journal of Educational Technology, 50(September), 280-293. https://doi.org/10.1111/bjet.12702

Kolberg, M., \& Tahir, A. I. (2020, 21. mars). Kreativ dugnad i kampen mot koronaviruset. NRK Urix. https://www.nrk.no/urix/kreativ-dugnad-i-kampen-mot-koronaviruset-1.14953689

Krumsvik, R. J., (2016). Introduksjon. I Krumsvik, R. J. (Red.), Digital læring i skole og lærerutdanning. 2 utgave (s. 17). Universitetsforlaget.

Kunnskapsdepartementet. (2019). Skaperglede engasjement og utforskertrang (Rapport F-4452 B). https://www.regjeringen.no/no/dokumenter/skaperglede-engasjement--og-utforskertrang/id2665820/

Lewis, E. T., \& Thurman, J. (2019). Tinkering and Hacking with Objects in the Art Classroom, Art Education, 72(4), 23-28, https://doi.org/10.1080/00043125.2019.1602497

Lutnæs, E., \& Fallingen, N. (2017). Bærekraftig utvikling gjennom skapende praksis. FormAkademisk forskningstidsskrift for design og designdidaktikk, 10(3), 1-19. https://doi.org/10.7577/formakademisk.1825

Maus, I. G., (2019). Developing design literacy for sustainability. Lower secondary students' life cycle thinking on their craft-based design products. FormAkademisk - forskningstidsskrift for design og designdidaktikk, 12(1), 1-18. https://doi.org/10.7577/formakademisk.1725 
Mehlum, K., (2018, 3. september). Makerspace, en kreativ lekeplass for alle. OsloMet. https://www.oslomet.no/studier/studenthistorier/makerspace-for-alle

Nielsen, L. M. (2019). Fagdidaktikk for Kunst og håndverk. I går, i dag, i morgen (2. utg.) Universitetsforlaget.

OsloMet. (2019). Emneplan for FKH3000. Fordypning i design, kunst og håndverk (høst 2019). https://student.oslomet.no/studier/-/studieinfo/emne/FKH3000/2019/H\%C3\%98ST

Padlet (n.d.). Padlet. https://no.padlet.com/

Papavlasopoulou, S., Giannakos, M., \& Jaccheri, L. (2017). Empirical Studies on the Maker Movement, a Promising Approach to Learning: A Literature Review. Entertainment Computing. 18(January), 57-78. https://doi.org/10.1016/j.entcom.2016.09.002

Raaheim, A., \& Nysveen, H. (2019). Studentaktiv læring. Erfaringer fra et kurs i produktutvikling og design. Uniped, 42(2). https://www.idunn.no/uniped/2019/02/studentaktiv_laering

Resnick, M., \& Rosenbaum, E. (2013). Designing for Tinkerability. In M. Honey \& D.E. Hunter (Eds.) Design, make, play. (pp. 163-181). Routledge.

Udir. (2019). Algoritmisk tenkning. Utdanningsdirektoratet. https://www.udir.no/kvalitet-ogkompetanse/profesjonsfaglig-digital-kompetanse/algoritmisk-tenkning/

Udir. (2020a). Respekt for naturen og miljøbevissthet. Overordnet del - verdier og prinsipper for grunnopplæringen. Utdanningsdirektoratet. https://www.udir.no/Ik20/overordnet-del/opplaringensverdigrunnlag/1.5-respekt-for-naturen-og-miljobevissthet/

Udir. (2020b). Skaperglede, engasjement og utforskertrang. Overordnet del-verdier og prinsipper for grunnopplæringen. Utdanningsdirektoratet. https://www.udir.no/lk20/overordnet-del/opplaringensverdigrunnlag/1.4-skaperglede-engasjement-og-utforskertrang/

Udir. (2020c). Kompetanse i fagene. Overordnet del - verdier og prinsipper for grunnopplæringen. Utdanningsdirektoratet. https://www.udir.no/lk20/overordnet-del/prinsipper-for-laring-utvikling-ogdanning/kompetanse-i-fagene/

Udir. (2020d). Grunnleggende ferdigheter. Overordnet del - verdier og prinsipper for grunnopplæringen. Utdanningsdirektoratet. https://www.udir.no/lk20/overordnet-del/prinsipper-for-laring-utvikling-ogdanning/grunnleggende-ferdigheter/?lang=nob 